\title{
PENDIDIKAN KARAKTER DAN MORALITAS BAGI ANAK
}

\author{
I Wayan Sutarwan ${ }^{l}$
}

\begin{abstract}
Abstrak
Anak merupakan generasi penerus yang eksistensinya sangat menentukan langkah kehidupan masyarakat, bangsa, dan negara Indonesia ke depan.Eksistensi generasi Penerus menjadi pelopor pergerakan kemerdekaan Indonesia kemudian menjadi tonggak yang sangat menentukan dalam sejarah perjalanan bangsa Indonesia.

Anak sebagai generasi penerus bangsa memiliki peran dan posisi yang strategis. Mereka merupakan harapan masa depan bangsa. Maju atau mundurnya bangsa dan Negara ada di pundak mereka. Pendidikan karakter dan moral sangat penting diberikan kepada anak sebagai generasi bangsa karakter adalah "kualitas atau kekuatan mental, moral, akhlak atau budi pekerti individu yang merupakan kepribadian khusus yang menjadi pendorong dan penggerak, serta yang membedakan dengan individu lain". Pembentukan karakter penting dilakukan bagi individu, tidak terkecuali generasi bangsa. Moral adalah perbuatan/tingkah laku/ucapan seseorang dalam berinteraksi dengan manusia. Apabila yang dilakukan seseorang itu sesuai dengan nilai rasa yang berlaku di masyarakat tersebut dan dapat diterima serta menyenangkan lingkungan masyarakatnya, maka orang itu dinilai memiliki moral yang baik, begitu juga sebaliknya. Orang tua harus menjadi yang terbaik dalam hal apapun. Banyak orang tua ingin mendorong anaknya untuk melakukan hal yang terbaik dalam kehidupannya.
\end{abstract}

\section{Kata Kunci, Pendidikan, Karakter, Moralitas}

\footnotetext{
${ }^{1}$ Penulis adalah Dosen Jurusan Dharma Duta STAHN-TP Palangka Raya
} 


\subsection{Pendahuluan}

Pesatnya pembangunan di era globalisasi yang berdampak majunya bidang informasi, komunikasi, dan tekhnologi, juga semakin berkembangnya ekonomi berbasis pengetahuan. Pada abad ekonomi berbasis pengetahuan ini, kemampuan intelektual, sosial, pengetahuan dan kecakapan hidup serta kredibilitas suatu bangsa merupakan modal utama bagi kesejahteraan dan kemajuan bangsa itu sendiri. Di era globalisasi ini perkembangan teknologi dan komunikasi semakin canggih nampaknya membawa perubahan pada setiap aspek kehidupan masyarakat baik positif maupun negatif. Perubahan itu telah membawa pergeseran nilai-nilai dalam masyarakat. Perubahan yang bersifat positif dapat membawa kehidupan manusia menjadi lebih baik dan perubahan yang bersifat negatif dapat merusak sendi-sendi kehidupan masyarakat.

Fenomena pada masyarakat dewasa ini, telah terjadi proses perubahan sangat erat pada masyarakat, akibatnya manusia akan berhadapan dengan suatu penyakit yang baru, ditandai oleh suatu krisis (Sudibya, 1994:70). Penyakit baru dimaksud adalah merosotnya nilainilai keagamaan. Hal senada juga diungkapkan oleh Suja (2002:18) bahwa ketidak siapan mental menghadapi globalisasi menyebabkan kebingungan perilaku. Memunculkan penyakitpenyakit masyarakat seperti korupsi, manipulasi, perampokan, penodongan, kenakalan remaja, dan lain-lain.

Anak merupakan generasi penerus yang eksistensinya sangat menentukan langkah kehidupan masyarakat, bangsa, dan negara Indonesia ke depan.Eksistensi generasi Penerus menjadi pelopor pergerakan kemerdekaan Indonesia kemudian menjadi tonggak yang sangat menentukan dalam sejarah perjalanan bangsa Indonesia. Selanjutnya dinamika peranan generasi Penerus yang dipelopori oleh generasi Bangsa yang berpendidikan tinggi berkembang di berbagai bidang kehidupan. Seiring dengan dinamika perkembangan politik, sosial, dan budaya di Indonesia peranan generasi penerus mengalami pasang surut. Di zaman globalisasi sekarang peranan generasi penerus terutama dalam mengimplementasikan nilai-nilai Pancasila dalam kehidupan masyarakat menjadi semakin surut.

Secara khusus persoalan generasi penerus dengan eksistensi jiwa mudanya semakin meninggalkan nilai-nilai Pancasila. Pancasila tidak lagi menjadi 
landasan utama dalam bertindak dan berperilaku dari berbagai segi kehidupan anak sebagai generasi penerus bangsa. Seharusnya Pancasila menjadi landasan utama yang dijadikan pedoman dan petunjuk arah bagi semua elemen bangsa Indonesia baik dalam kehidupan individu, bermasyarakat, dan bernegara.

Anak sebagai generasi penerus bangsa memiliki peran dan posisi yang strategis. Mereka merupakan harapan masa depan bangsa. Maju atau mundurnya bangsa dan Negara ada di pundak mereka. Kalau mereka maju maka majulah Negara, tetapi kalau meraka bobrok, mundur, dan loyo, maka mundurlah Negara. Sudut pandang psikologi sebagai generasi penerus memiliki potensi yang bisa dikembangkan secara maksimal. Potensi mereka yang prospektif, dinamis, energik, penuh vitalitas, patriotism dan idealism harus dikembangkan melalui pendidikan dan pelatihan yang terrencana dan terprogram.

Anak sebagai generasi penerus juga memiliki kemampuan potensial yang bisa diolah menjadi kemampuan actual. Selain itu juga memiliki potensi kecerdasan intelektual, emosi dan sosial, berbahasa, dan kecerdasan seni yang bisa diolah menjadi kecerdasan aktual yang dapat membawa mereka kepada prestasi yang tinggi dan kesuksesan. Mereka memiliki potensi moral yang dapat diolah dan dikembangkan menjadi moral yang $p$ ositif sehingga mampub erpartisipasi aktif dalam pembangunan bangsa dan Negara yang penuh dengan kejujuran, Potensi mereka yang prospektif, dinamis, energik, penuh vitalitas, patriotisme dan idealisme telah dibuktikan ketika jaman Pergerakan Nasional, pemuda pelajar telah banyak memberikan kontribusi dalam kehidupan berbangsa dan bernegara. Hal itu bisa terwujud apabila semua potensi mereka dikembangkan dan salah satunya adalah potensi moral.

\subsection{Pembahasan}

\subsubsection{Pendidikan}

Pendidikan adalah salah satu bentuk interaksi manusia sekaligus tindakan sosial yang dimungkinkan berlaku melalui suatu jaringan hubungan-hubungan kemanusiaan yang mampu menentukan watak pendidikan dalam suatu masyarakat melalui peranan-peranan individu di dalamnya yang diterapkan melalui proses pembelajaran. Pendidikan adalah usaha sadar dan bertujuan untuk mengembangkan kualitas 
manusia. Sebagai suatu kegiatan yang sadar akan tujuan, maka dalam pelaksanaannya berada dalam suatu proses yang berkesinambungan dalam setiap jenis dan jenjang pendidikan. Semuanya berkaitan dalam suatu sistem pendidikan yang integral. Jadi pendidikan sebagai suatu sistem, tidak lain dari suatu totalitas fungsional yang terarah pada suatu tujuan. Setiap subsistem yang ada dalam sistem tersusun dan tidak dapat dipisahkan dari rangkaian unsur-unsur atau komponenkomponen yang berhubungan secara dinamis dalam suatu kesatuan (Djamarah, 2008:22).

Jadi dari pengertian diatas, dapatlah dikemukakan bahwa pendidikan itu adalah usaha sadar yang dilaksanakan dengan sengaja oleh orang yang lebih tua (orang tua dan guru), untuk mempengaruhi orang lain (anak dan siswa) yang mentransfer nilai-nilai tertentu kepada siswa, guna mempermudah siswa menghadapi persoalanpersoalan hidupnya untuk mencapai tujuan hidupnya. Pendidikan bukan hanya saja berlangsung secara formal disekolah saja, melainkan pada semua lingkungan sosialnya, dalam prosesnya itu manusia mendapatkan wawasan, ilmu pengetahuan, keterampilan dari orang lain yang berguna bagi kehidupannya. Proses itu berlangsung seumur hidup yang dilaksanakan di dalam lingkungan keluarga, sekolah maupun masyarakat. Oleh karena itu usaha pendidikan adalah tanggung jawab dari keluarga, masyarakat, dan pemerintah.

Ihsan (2003:40), mengungkapkan pendidikan seumur hidup adalah adalah suatu proses belajar yang terus menerus (kontinu) dari semasih dalam kandungan hingga meninggal dunia. Bedasarkan ide tersebut konsep pendidikan seumur hidup sering pula dikatakan sebagai belajar berkesinambungan (continuing learning). Dengan terus menerus belajar, seseorang tidak akan ketinggalan zaman dan dapat memperbaharui pengetahuannya, terutama bagi mereka yang sudah berusia lanjut. Melalui pengetahuan yang selalu diperbaharui ini, mereka tidak akan terasing dan generasi muda tidak akan menjadi snile atau pikun secara dini, dan tetap dapat memberikan sumbangan pemikiran bagi kehidupan di lingkungannya.

\subsubsection{Karakter dan Moralitas}

\section{Pendidikan Karakter}

Istilah karakter berasal dari bahasa Yunani, charassein, yang berarti "to mark"atau menandai dan memfokuskan bagaimana mengaplikasikan nilai kebaikan dalambentuk 
tindakan atau tingkah laku. Dari istilah tersebut kemudian berkembang menjadi pengertian karakter yang diartikan sebagai tanda khusus atau pola perilaku "anindividual's pattern of behavior ... his moral contitution" (Karen E. Bohlin, Deborah Farmer,dan Kevin Ryan, 2001: 1).

Menurut Hidayatullah (2010:14), karakter adalah "kualitas atau kekuatan mental, moral, akhlak atau budi pekerti individu yang merupakan kepribadian khusus yang menjadi pendorong dan penggerak, serta yang membedakan dengan individu lain". Pembentukan karakter penting dilakukan bagi individu, tidak terkecuali remaja. Pentingnya penanaman karakter sangat penting dilakukan bagi remaja. Realitanya para remaja, sebagian besar tidak mendapat perhatian yang cukup dari kedua orang tua di dalam keluarga. Karakter menurut Kamus Besar Bahasa Indonesia (2008) merupakan sifat-sifat kejiwaan, akhlak atau budi pekerti yang membedakan seseorang dari yang lain. Dengan demikian karakter adalah nilai-nilai yang unikbaik yang terpateri dalam diri dan terejawantahkan dalam perilaku. Karakter secara koheren memancar dari hasil olah pikir, olah hati, olah rasa dan karsa, serta olahraga seseorang atau sekelompok orang.

Pendidikan Karakter Sering disamakan dengan pendidikan Budhi pekerti. Seseorang dapat dikatakan berkarakter atau berwatak jika telah berhasil menyerap nilai $\mathrm{d}$ a n keyakinan y a $\mathrm{g}$ dikehendaki masyarakat serta serta digunakan sebagai kekuatan moral dalam hidupnya. Pembentukan karakter penting dilakukan bagi individu, tidak terkecuali remaja.

\section{Faktor Pendidikan Karakter}

Faktor lingkungan dalam konteks pendidikan karakter memiliki peran yang sangat peting karena perubahan perilaku peserta didik sebagai hasil dari proses pendidikan karakter sangat ditentunkan oleh faktor lingkungan ini. Dengan kata lain pembentukan dan rekayasa lingkungan yang mencakup diantaranya 
lingkungan fisik dan budaya sekolah, manajemen sekolah, kurikulum, pendidik, dan metode mengajar. Pembentukan karakter melalui rekayasa faktor lingkungan dapat dilakukan melalui strategi :

1. Keteladanan

2. Intervensi

3. Pembiasaan yang dilakukan secara Konsisten

4. Penguatan.

Dengan kata lain perkembangan dan pembentukan karakter memerlukan pengembangan keteladanan yang ditularkan, intervensi melalui proses pembelajaran, pelatihan, pembiasaan terus-menerus dalam jangka panjang yang dilakukan secara konsisten dan penguatan serta harus dibarengi dengan nilai-nilai luhur (https://pndkarakter.wordpress.co $\mathrm{m} /$ category/tujuan-dan-fungsipendidikan-karakter)

\section{Pendidikan Moral}

Moral adalah ajaran
tentang baik buruk yang
diterima umum mengenai
perbuatan, sikap, kewajiban dan
sebagainya. Pengertian moral
juga memiliki kesetaraan atau
kesamaan arti dengan
pengertian akhlak, budi pekerti,

dan susila. Moral sebenarnya memuat dua segi berbeda, yakni segi batiniah dan segi lahiriah. Orang yang baik adalah orang yang mempunyai sikap batin yang baik dan melakukan perbuatan yang baik pula. Dengan kata lain, moral hanya dapat diukir secara tepat a pabila kedua seginya diperhatikan. Orang hanya dapat dinilai secara tepat apabila hati maupun perbuatannya ditinjau bersama. Moralitas adalah kualitas dalam perbuatan manusia yang menunjukkan bahwa perbuatan itu benar atau salah, baik atau buruk. Moralitas mencakup pengertian tentang baikburuknya perbuatan manusia.Moralitas dapat objektif atau subjektif. Moralitas objektif memandang perbuatan semata sebagai perbuatan yang telah dikerjakan, bebas lepas dari pengaruh sukarela pihak pelaku. Lepas dari segala keadaan khusus si pelaku yang dapat mempengaruhi atau mengurangi penguasaan diri dan bertanya apakah orang yang sepenuhnya menguasai dirinya diizinkan dengan sukarela menghendaki perbuatan 
tersebut. Moralitas subjektif adalah moralitas yang memandang perbuatan sebagai perbuatan yang dipengaruhi pengertian dan persetujuan si pelaku individu. Selain itu juga dipengaruhi, dikondisikan oleh 1 a t a r belakang y a, pendidikannya, kemantapan emosinya, dan sifat-sifat pribadi lainnya. Persoalan pendidikan moral sebenarnya menjadi tanggung jawab setiap elemen dalam masyarakat. Baik itu keluarga, sekolah, lembaga keagamaan maupun lembaga sosial lainnya. Dalam artian harus ada komitmen dan langkah secara bersama dalam usaha pemberian bimbingan moralitas kepada generasi bangsa. Keluarga, sebagai lembaga pendidikan pertama yang diterima anak keluarga harus mampu memenuhi semua kebutuhan dasar manusia. Meliputi landas a n pembentukan watak dan kepribadian, penanaman dan pengenalan agama serta nilainilai moral dalam kehidupan masyarakat. Sosok orang tua harus mempunyai sikap ing ngarsa sung tuladha, ing madya mangun karsa, dan tut wuri handayani. Ing ngarsa sung tuladha berarti orang tua berdiri di depan (pemimpin) dengan senantiasa memberi tauladhan yang baik. Ing madya mangun karsa berarti posisi orang tua sebagai pembangkit/penggugah niat anak untuk berbuat kebajikan. Tut wuri handayani berarti posisi orang tua sebagai pemberi dorongan moral (memotivasi).

B erusaha untuk mengembangkan pola perilaku seseorang sesuai dengan kehendak masyarakatnya. Kehendak itu berwujud moralitas atau kesusilaan yang berisi nilai-nilai dan kehidupan yang berada dalam masyarakat. Karena menyangkut dua asfek inilah, yaitu (a) Nilai-nilai, (b) Kehidupan Nyata, maka pendidikan moral lebih banyak membahas masalah dilemma (seperti makan buah simalakama) yang berguna untuk mengambil keputusan moral yang terbaik bagi diri dan mas yarakatnya. moral merupakan kondisi pikiran, perasaan, ucapan, dan perilaku manusia yang terkait dengan nilai-nilai baik dan buruk. Moral secara ekplisit adalah hal-hal yang berhubungan 
dengan proses sosialisasi individu, tanpa moral manusia tidak bisa melakukan proses sosialisasi. Moral adalah nilai keabsolutan dalam kehidupan bermasyarakat secara utuh. Penilaian terhadap moral diukur dari kebudayaan masyarakat setempat. Moral adalah perbuatan/tingkah laku/ucapan seseorang dalam berinteraksi dengan manusia. Apabila yang dilakukan seseorang itu sesuai dengan nilai rasa yang berlaku di masyarakat tersebut dan dapat diterima serta menyenangkan lingkungan masyarakatnya, maka orang itu dinilai memiliki moral yang baik, begitu juga sebaliknya. Moral adalah produk dari budaya dan agama. Setiap budaya memiliki standar moral yang berbeda-beda sesuai dengan sistem nilai yang berlaku dan telah terbangun sejak lama. Moral juga dapat diartikan sebagai sikap, perilaku, tindakan, kelakuan yang dilakukan seseorang pada saat mencoba melakukan s e s u a t u berdasarkan pengalaman, tafsiran, suara hati, serta nasihat, dan yang lainnya. Maka dapat disimpulkan bahwa pengertian pendidikan moral adalah usaha yang dilakukan secara terencana untuk mengubah sikap, perilaku, tindakan, kelakuan yang dilakukan peserta didik agar mampu berinteraksi dengan lingkungan masyarakatnya sesuai dengan nilai moral dan kebudayaan masyarakat setempat.

Globalisasi memiliki sisi positif dan negatif terhadap pendidikan moral. Disatu sisi, arus globalisasi merupakan harapan yang akan memberikan berbagai kemudahan bagi kehidupan manusia. Namun disisi lain, era globalisasi juga memberikan dampak yang sangat merugikan. Dengan perkembangan sektor teknologi dan informasi, manusia tidak lagi harus menunggu waktu, untuk bisa mengakses berbagai informasi dari seluruh belahan dunia, bahkan yang paling pelosok sekalipun. Kondisi ini menjadikan tidak adanya sekat serta batas yang mampu untuk menghalangi proses transformasi kebudayaan. John Neisbitt, menyebutkan kondisi seperti ini sebagai "gaya hidup global", yang ditandai dengan berbaurnya budaya antar bangsa, seperti terbangunnya 
tatacara hidup yang hampir sama, kegemaran yang sama, serta kecenderungan yang sama pula, baik dalam hal makanan, pakaian, hiburan dan setiap aspek kehidupan manusia lainnya. Kenyataan semacam ini, akan membawa implikasi pada hilangnya kepribadian asli, serta terpoles oleh budaya yang cenderung lebih berkuasa. Dalam konteks ini, kebudayaan barat yang telah melangkah jauh dalam bidang industri serta teknologi informasi, menjadi satu-satunya pilihan, sebagai standar modernisasi, yang akan diikuti dan dijadikan kiblat oleh setiap individu. Globalisasi menyebabkan perubahan sosial yang memunculkan nilai-nilai yang bersifat pragmatis, materialistis d a n individualistik.

4 Peran orang tua dalam pendidikan karakter dan moral

Anak adalah anugerah dari sang pencipta, orang tua yang melahirkan anak harus bertangung jawab terutama dalam soal mendidiknya, baik ayah sebagai kepala keluarga maupun ibu sebagai pengurus rumah tangga. Keikutsertaan orang tua dalam mendidik anak merupakan awal keberhasilan orang tua dalam keluarganya apabila sang anak menuruti perintah orang tuanya terlebih lagi sang anak menjalani didikan sesuai dengan perintah agama. Bobroknya moral seorang anak dan remaja bisa diakibatkan salah satu kesalahan dari orangtuanya seperti dalam hal mendidik anak terlalu keras. keluarga yang sedang bermasalah (broken home). Hal tersebut dapat membuat anak $\mathrm{m}$ e n jadi orang y ang temperamental. Kebanyakan dari orang tua tidak memikirkan hal ini, mereka berasumsi jika mereka menjalani hidup sebagaimana yang sedang mereka jalani, peran pengasuhan akan terus dengan sendirinya. Dalam era modernisasi sekarang ini, peran penting orang tua sangat dibutuhkan.

Berkenaan dengan perkembangan kecanggihan teknologi. Sesuatu yang tidak dapat dihindari bahwa teknologi berkembang dengan pesat sehingga penggunaannya banyak digunakan tidak semestinya, Teknologi IT yang paling sering digunakan para anak muda sekarang adalah akses internet yang mudah 
ditemui, padahal pemerintah sudah mengeluarkan undangundang anti pornoaksi dan pornografi tapi masih saja mereka kerap mengakses konten yang berbau negatif. Yang jelas dapat merusak moral sang anak. Teknologi canggih yang semestinya diciptakan untuk menambah wawasan malah berakibat pada moral yang jelek. Pergaulan merupakan interaksi antara beberapa orang baik berupa kekeluargaan, organisasi, ataupun masyarakat. Melalui pergaulan kita akan berkembang karena jadi tahu tentang tata cara bergaul. Sehingga menjadikan individu yang bersosial karena pada dasarnya manusia memang makhluk sosial. Namun pergaulan di era modernisasi ini telah banyak disalah artikan terutama dikalangan anak muda. Sekarang kata-kata pergaulan bebas sudah tidak asing lagi didengar oleh siapapun dan jelas termasuk dalam kategori pergaulan yang negatif. Pergaulan yang negatif adalah salah satu dari sekian banyak penyebab kehancuran sang anak. Saat ini dapat kita lihat banyaknya sistem pergaulan kawula muda yang mengadopsi gaya ala barat. Satu lagi permasalahan yang sering ditakuti oleh orang tua yaitu narkoba, sudah jelas barang haram ini dikategorikan sebagai barang berbahaya dan terlarang yang bisa merusak generasi bangsa.

Narkoba menjadi jurang kehancuran bagi sang anak. Ironisnya memakai barang haram ini juga sudah menjadi tren remaja sekarang dengan anggapan bila mengkonsumsi barang ini akan menjadi senang atau yang dikenal dengan bahasa gaulnya (fly). Padahal sudah jelas menurut kesehatan mengkonsumsi barang-barang sejenis narkoba sangat merusak kesehatan terutama pada sistem syaraf apalagi dengan mengkonsumsi barang ini akan membuat ketagihan dan ketergantungan, ini sungguh menakutkan. Apakah kita sebagai orang tua ingin melihat anak hancur masa depannya karena kesalahan yang tidak semestinya terjadi? Di sinilah peran penting orang tua dalam mengontrol dan mengawasi sang buah hati. Menjadi orang tua bukan soal siapa kita, tetapi apa yang dilakukan . 
Pengasuhan tidak hanya mencakup tindakan tetapi mencakup pula apa yang kita kehendaki agar sang buah hati kita mengerti akan hidup. Apa artinya hidup dan bagaimana menjalani kehidupan ini dengan baik. Semua pasti ingin menghendaki hal yang terbaik untuk anak-anaknya.

Orang tua ingin mendisiplinkan, mendorong, dan menasihati agar mereka berhasil menjalani kehidupan sedari kanak-kanak hingga sampai dewasa. Orang tua harus menjadi yang terbaik dalam hal apapun. Banyak orang tua ingin mendorong anaknya untuk melakukan hal yang terbaik dalam kehidupannya. Termasuk ingin membuat buah hatinya untuk bebas mengeluarkan dan menggali bakat dan minat yang dimiliki sang anak. Hal yang semestinya dipahami adalah banyak anak mengalami kesulitan untuk membedakan antara menerima atau menolak tindakan atas apa yang mereka lakukan. Misalnya saja penerimaan orang tua terhadap prestasi yang dimiliki atau dicapai anak bisa dianggap anak sebagai rasa cinta orangtua kepadanya,tetapi penolakan yang dilakukan orang tua terhadap tindakan yang dilakukan anak membuat anak beranggapan mereka tidak dicintai dan disayangi lagi. Setiap anak perlu tahu kalau mereka disayangi dan dicintai orang tua dengan sepenuh hati, meskipun sebaliknya, setiap orang tua harus mencintai dan menyayangi sang buah hati tanpa syarat apapun, baik buruknya sifat maupun sikap yang dimiliki sang buah hati, mereka harus menerima kekurangan dan kelebihan yang dimiliki oleh anak,semua anak ingin diperhatikan kedua orang tuanya. Pernyatan ini sangat sederhana bagi kita semua, tetapi sifatnya fundamental bagi kedua orang dalam mengasuh buah hati mereka. Karenanya dalam pola pengasuhan sebaiknya setiap orang tua tidak boleh membedakan anak satu sama lain.

Kita juga tidak semestinya membedakan buah hati mereka, baik dalam mendidik maupun memberikan perhatian kepada sang anak. Harus ada rasa keadilan, tidak boleh pilih kasih, karena akan menimbulkan kecemburuan 
diantara anak. Yang ditakutkan nanti akan membuat anak menjadi rusak, bahkan berpikir kalau mereka tidak disayangi lagi, bahkan ada anak yang beranggapan kalau mereka itu bukan anak dari orang tua mereka sendiri, karena selalu dibeda-bedakan dengan yang lainnya.Orang tua tidak seharusnya memperlihatkan emosi yang negatif kepada anak-ananya. Ketidakmampuan setiap orang tua dalam mengontrol emosi membuat anak menjadi temperamental dan mempunyai sifat maupun sikap yang buruk yaitu mudah emosional. Akibatnya orang tua yang demikian tidak bisa menjadi model atau peran yang baik untuk anak-anaknya dalam mengontrol anak dan mengasuh buah hatinya.

Tujuan orang tua $\mathrm{s}$ e b e n a r n y a u n t u k mengkomunikasikan kepada buah hatinya bahwa mereka memiliki hak untuk merasakan apapun yang mereka rasakan, Mengajari sang buah hati untuk menghargai dan menikmati setiap saat dalam kehidupan sehingga mampu memberi motivasi kepada anak dalam mencegah serta menghadapi masalah yang mereka hadapi kedepan. Terkadang orang tua sering lupa untuk berinteraksi dengan anak- anaknya. Ada diantara mereka yang lebih mementingkan pekerjaan dari pada melakukan hal itu. Bagi mereka hal itu tidak perlu d i l a k ukan. M e r e k a beranggapan bahwa materi yang dibutuhkan anak, Padahal seorang anak tidak hanya membutuhkan materi namun juga perhatian dan interaksi dengan orangtuanya. Mereka membutuhkan komunikasi dengan orang tuanya, mereka juga ingin bertukar pikiran dengan orang tuanya. Mereka ingin menceritakan pegalaman apa yang mereka rasakan sehari-hari baik itu pangalaman yang baik maupun pengalaman yang buruk. Sekali lagi yang perlu diingat oleh kedua orang tua adalah jika seorang anak a $\mathrm{t} \mathrm{a} \mathrm{u} \mathrm{rem} \mathrm{a} \mathrm{ja} \mathrm{k} \mathrm{u} \mathrm{rang}$ mendapatkan perhatian dari orang tua, besar kemungkinan dia akan menjadi seorang anak d a n r e m a j a y a n g temperamental.

Sang anak menjadi bebas dalam melakukan segala hal, baik itu dalam hal kebaikan maupun keburukan. Sebagai 
orangtua seharusnya memiliki kemampuan untuk memusatkan perhatian pada perilaku positif serta tak lupa pada perilaku buruk sang anak. Sebagai orang tua yang baik, jangan melihat keburukan atau kebaikan. Namun lihatlah dari tata cara bergaul sang anak, dengan siapa bergaul, bagaimana luas pergaulannya. Bukan sekedar untuk membatasi sang anak dalam bergaul namun diharapkan impian melihat anak sukses mengarungi kehidupan tanpa mengalami kesalahan dalam pergaulan baik dilingkungan keluarga, atau lingkungan luar menjadi sebuah kenyataan. Manfaatnya kembali ke orang tua, sebab sang anak lalu menjadi orang yang menghargai kedua orang tua.

\subsection{Simpulan}

1. Karakter secara koheren memancar dari hasil olah pikir, olah hati, olah rasa dan karsa, serta olahraga seseorang atau sekelompok orang. Pendidikan Karakter Sering disamakan dengan pendidikan Budhi pekerti. Seseorang dapat dikatakan berkarakter atau berwatak jika telah berhasil menyerap nilai dan keyakinan yang dikehendaki masyarakat serta serta digunakan sebagai kekuatan moral dalam hidupnya.

2. Moralitas adalah kualitas dalam perbuatan manusia yang menunjukkan bahwa perbuatan itu benar atau salah, baik atau buruk. Moralitas mencakup pengertian tentang baik-buruknya perbuatan manusia.

3. Orang tua tidak seharusnya memperlihatkan emosi yang negatif $\mathrm{k}$ e $\mathrm{pad}$ a a n a k - a n a n y a . Ketidakmampuan setiap orang tua dalam mengontrol emosi membuat anak menjadi temperamental dan mempunyai sifat maupun sikap yang buruk yaitu mudah emosional. Akibatnya orang tua yang demikian tidak bisa menjadi model atau peran yang baik untuk anak-anaknya dalam mengontrol anak dan mengasuh buah hatinya.

\section{Daftar Pustaka}

Djamarah, Syaiful Bahri. 2008. Psikologi Belajar. Jakarta: Rineka Cipta.

Ihsan, Fuad. 2003. Dasar-dasar Kependidikan cetakan ke tiga. Jakarta: Rineka Cipta.

Karen E. Bohlin, Deborah Farmer,

Kevin Ryan.(2001). Building

Character in School Resource Guide.

San Fransisco: Jossey Bass.

Tim, 2008. KamusBesar Bahasa 
Indonesia, Jakarta : Balai

Pustaka.

(https://pndkarakter.wordpress.com/cat

egory/tujuan-dan-fungsi-pendidikan-

karakter)

Jurnal Dharma Duta 2017 VOL XV, Januari - Juni 2017 
Jurnal Dharma Duta 2017 VOL XV, Januari - Juni 2017 